\title{
Theatre, museum, basement, camp
}

The idea of building type - for example, housing, office, or library - remains significant in architectural practice and research. The study of building types is assumed to provide operative professional knowledge: studying the form of previous buildings to improve the layout of future ones. This issue of arq presents a series of reflections on particular building types and, more implicitly, on what typological research can offer.

Elizabeth Merrill critiques the life-in-use, and alteration, of the Center for Contemporary Art, Cincinnati, USA, designed by Zaha Hadid Architects, opened in 2003 and refurbished in 2015 (pp. 210-224). Merrill ponders the idea of 'the good museum', reflecting on the relative contributions of art and commerce to the making of the city. Fernando Quesada López, meanwhile, returns to debates in Italian architectural theory from the 1960 s and 1970 s that articulated three terms representing different relations between theatre and the city: 'the temple, the machine, and the caravan' (pp. 225-238). Deeper in Western history, Randall Teal analyses the diagrammatic layout of Roman camps (pp. 239-253). Their 'elasticity' and 'ultimate indeterminacy', he argues, exported Roman cultural and religious values into areas of territorial conquest, providing 'an iconic and procedural image of Roman order and identity' that became concretised in Roman city form. In contrast, Sophie Baldwin, Elizabeth Holroyd, and Roger Burrows quantify, map, and analyse elite residential basement developments across the seven wealthiest boroughs of contemporary London (pp. 267-282). These so-called 'iceberg basements' are a consequence of 'super-gentrification' mixed with strict planning policy, where the only way to substantially extend formerly modest houses is to bury elaborate extensions of sometimes two or three storeys beneath them. Relatedly, Lisa Moffitt considers the thermoheliodon - not a building type, but the device featured in Victor Olgyay's famous Design with Climate (1963), that was subsequently used to explore the environmental characteristics of particular building types.

None of these investigations can be understood as conventional architectural typological studies. They draw from particular research methods, including criticism, theory, diagramming, historical practices, mapping, quantitative analysis, and environmental history. This issue of arq thus outlines a variety of potential approaches to typological study in architectural research, illustrating alternative methods and values. It highlights connected ideas about what typological study can be for: the design of future projects, as conventionally understood; exploring relations between architecture and city-making; and formal, social, or political critique. 